УДК: 61:007

DOI: http://dx.doi.Org/10.11603/mie.1996-1960.2016.2.6483

\title{
ІНФОРМАЦІЙНА СИСТЕМА ДЛЯ МЕДИКО-ГЕНЕТИЧНОЇ ЛАБОРАТОРІЇ
}

\author{
В. 3. Стецюк, А. Й. Савицький, Т. П. Іванова ${ }^{1}$, Н. В. Ольхович ${ }^{1}$, Ю. О. Луговський \\ Національний технічний університет України «Київський політехнічний інститут» \\ Національна дитяча спеціалізована лікарня «ОХМАТДИТ»
}

В статті описано програмний продукт, розроблений для оптимізації роботи працівників лабораторії та лікарів. Подано перелік основних функцій додатка та вказано переваги для користувача при його використанні.

Ключові слова: лабораторні дослідження, база даних, додаток, медичні картки.

\section{ИНФОРМАЦИОННАЯ СИСТЕМА ДЛЯ МЕДИКО-ГЕНЕТИЧЕСКОЙ ЛАБОРАТОРИИ}

\author{
В. 3. Стецюк, А. И. Савицкий, Т. П. Иванова ${ }^{1}$, Н. В. Ольхович ${ }^{1}$, Ю. А. Луговский \\ Национальный технический университет Украины \\ «Киевский политехнический институт» \\ Национальная детская специализированная больница «ОХМАТДЕТ»
}

\begin{abstract}
В статье описан программный продукт, разработанный для оптимизации работы сотрудников лаборатории и врачей. Перечислены основные функции приложения и указаны преимущества для пользователя при его использовании.
\end{abstract}

Ключевые слова: лабораторные исследования, база данных, приложение, анализы.

\section{INFORMATION SYSTEM FOR MEDICAL AND GENETIC LABORATORY}

\author{
V. Z. Stetsyuk, A. I. Sawickiy, T. P. Ivanova ${ }^{1}$, N. V. OIhovich ${ }^{1}$, Y. O. Luhovskii \\ National Technical University of Ukraine "Kyiv Polytechnic Institute" \\ National Children's Hospital "OKHMATDYT»
}

\begin{abstract}
In article describes an application that was developed to optimize laboratory staff and doctors work.
The article begins with showing which laboratories materials and internal processes were used in investigation. Then describes how based on this result application was developed.

The program provides functionality that can be divided into several parts: saving, editing and deleting data, viewing data, search, data processing, creating documents, authorization, distributed work. These functions described enough to understand how they present in application, which data they are using and which output they produce. Also describes advantages for each functionality and shows how it helps doctors and laboratory staff.
\end{abstract}

Key words: laboratory research, database, application, analyzes.

Вступ. У сучасній медицині для встановлення вірного діагнозу чи призначення лікування, в деяких випадках, достатньо зовнішнього огляду, однак, коли цієї інформації не вистачає беруть аналізи у пацієнта, щоб отримати необхідну кількість даних про його стан здоров'я.

В клініках, що займаються обстеженням пацієнтів зі складними захворюваннями, проводять чимало досліджень, які з часом повторюють, щоб відстежити динаміку зміни здоров'я. Зазвичай досліджують певний набір аналізів. I оскільки різні дослідження виконуються за певний час їх результати отримуються протягом певного періоду. В такій роботі важливим постає питання організації роботи лікаря. Вона повинна бути налагодженою та чіткою, щоб виконувати її швидко та вірно. На сьогоднішній день в лікарнях для запису інформації по пацієнту та його аналізів використовують паперові картки. Це є не зручно і якщо з цією карткою будуть працювати більше чим одна людина цей процес ускладнюється, бо щоб записати чи прочитати з неї дані потрібно знайти картку. Це стає проблемою

() В. 3. Стецюк, А. Й. Савицький, Т. П. Іванова, Н. В. Ольхович, Ю. О. Луговський 
коли лікарі, що призначають аналізи та лабораторія знаходяться на різних поверхах чи корпусах. I стає надзвичайним складним, якщо потрібно отримати статистичну інформацію по пацієнту чи пацієнтах.

Мета дослідження - оптимізація роботи лаборантів і лікарів.

Матеріали і методи дослідження. Матеріалом дослідження стала робота лаборантів, які працюють 3 аналізами, та робота лікаря, який оглядає пацієнтів і призначає дослідження. Вивченню підлягав увесь процес від моменту звернення пацієнта до отримання кінцевих результатів дослідження, в тому числі медичні картки та форми з результатами аналізів.

Результати та їх обговорення. Результатом дослідження роботи лабораторії та аналізу медичних карток став програмний продукт, що оптимізує роботу персоналу лабораторії та лікарів.

Програмний додаток реалізує такі функції:

- збереження даних;

- редагування даних, видалення даних зі словників;

- виведення даних;

- пошук;

- обробка даних, статистичний підрахунок;

- створення документів;

- розподілена робота;

- авторизація.

Додаток дає можливість зберігати інформацію про пацієнта. Це мінімальний набір даних, за яким пацієнт ідентифікується в системі, також є можливість зберігати призначені йому дослідження та результати аналізів.

Призначати пацієнту дослідження та вказати список аналізів можна лише після заповнення словників. Словники є набором даних, що вносяться один раз і використовуються програмою при заповненні форм досліджень та аналізів. До них відносяться матеріал, показник, метод дослідження та проставлені залежності між ними, ПІБ лікаря тощо. Це дало можливість вносити всі значення словників за допомогою випадного списку, а проставлені залежності між матеріалом, показником та методом дослідження унеможливлюють неправильне введення даних. Це прискорює роботу, оскільки не потрібно вводити дані вручну.

Всі збережені дані про пацієнта, назви матеріалів та методів можна редагувати. Зі словниками доступна функція видалення запису. Однак насправді запис не видаляється з бази даних, а тільки забирається $з$ випадного списку при створенні нових досліджень або аналізів.
Додаток дає можливість перегляду всієї введеної інформації при відкритті форми з даними про пацієнта та його аналізи. Також виводяться списки зі зведеною інформацією, наприклад, список призначених пацієнту досліджень, де кожен запис показує кількість призначених аналізів та їх готовність.

Пошук в додатку перебуває на головній сторінці, де відображається список наявних у системі пацієнтів. За його допомогою можна знайти дані на певного пацієнта, що вже проходив дослідження, призначити йому нове або переглянути інформацію щодо нього.

Обробка даних є значною частиною додатка і використовується для реалізації різного функціонала. Вона застосовується для формування списку пацієнтів 3 новими або незавершеними дослідженнями. Завдяки такому списку лаборантові не потрібно шукати конкретного пацієнта, відкривати форму 3 його даними, і потім вже відкривати форму 3 дослідженням, а можна просто відкрити їі зі списку і внести результат аналізу. Якщо всі результати призначених аналізів записано, цей запис зникає зі списку.

Також обробка даних застосовується при формуванні статистики. На формі вибираються поля та вводяться значення, за якими проводиться фільтрація даних. Після отримання списку подається статистика, що є відношенням знайденої кількості аналізів до загальної. Також розроблено спеціальний пошук пацієнтів, яким декілька разів за певний час призначалися однакові дослідження.

Додаток має функцію створення документа 3 результатами аналізів. Вона дає можливість сформувати документ iз розширенням .doc, в якому виводиться коротка інформація про пацієнта, список призначених аналізів, їх результати та норми результатів.

Даний додаток може бути встановлено на будьякій кількості комп'ютерів, що перебувають в одній локальній мережі. Їх можна налаштувати на використання однієї бази даних. Це дасть лікарям можливість завжди мати доступ до останньої інформації.

Розроблено авторизацію, що унеможливлює вхід у систему без введення логіна та пароля.

Методи вирішення завдання. Для розробки даного продукту використовувалась мова програмування С\# та середовище розробки Visual Studio. Для зберігання інформації використовується сервер бази даних MS SQL. 
Висновки. Результатом даного дослідження була оптимізація роботи лаборантів і лікарів за допомогою розробленого програмного продукту.

Додаток прискорює процес, що починається обстеженням пацієнта та закінчується отриманням усіх його аналізів. Витрачається менше часу на введення даних у форму, а завдяки словникам зменшується можливість помилки. Пошук та статистика дозволяють швидко знайти інформацію по одному чи групі пацієнтів, які мають спільні дані. Завдяки використанню одного серверу бази даних, 3 додатком можуть працювати відразу декілька людей і отримувати останню введену інформацію. Автоматичне створення документів позбавляє лікарів необхідності вводити результати аналізів вручну.

Отже, завдяки представленій розробці підвищується працездатність лаборантів і лікарів, зменшується можливість помилки, витрачається менше часу на пошук інформації та формування звітів.

\section{Література.}

1. Visual C\# 2008 : базовый курс / К. Уотсон, К. Нейгел, Д. Рид [и др.]; пер. с англ. Я. П. Волковой, Д. Я. Иваненко, Ю.И. Корниенко [и др.]; зав. ред. С. Н. Тригуб. - М. : И. Д. Вильямс, 2009. - 1216 с.

2. Ицик Б. Microsoft Sql Server 2008. Основы T-SQL / Б. Ицик ; пер. с англ. Т. Коротяевой; глав. ред. Е. Конду кова; зав. ред. Г. Добин. - Спб. : БХВ-Петербург, 2009. - 432с.: ил.

3. Симан М. Внедрение зависимостей в .NЕT. - Спб.: Питер, 2013. - 464 с.: ил. 